\title{
Computer packages that contain the FFT
}

\author{
DOUGLAS R. EDDY and FREDERICK J. BREMNER \\ Trinity University, San Antonio, Texas 78212
}

\begin{abstract}
This paper critiques a set of software (i.e., SAS, BMDP, LSP) that contain a Fourier analysis program. In addition, this paper discusses both general-purpose software that runs a Fourier analysis and special Fourier analysis hardware. Some examples of the efficacy of commercially available software and hardware are given.
\end{abstract}

The purpose of this paper is to review the various commercially available computer programs that run a Fourier analysis of psychological and physiological data. The Fourier analysis is now available in the BMDP and SAS packages, as well as on laboratory minicomputers such as the Digital Equipment Corporation's PDP-11 series. In fact, fast Fourier transforms (FFTs) have been written for microcomputers such as the Apple II. The information in this article should be helpful to those wishing to add FFT analysis to their research capability. Since all FFTs are not equal with respect to their specific features, these idiosyncrasies need to be known before a product is purchased. The limitations of various products are especially critical for on-line usage, in which analysis time can range from a few milliseconds to several minutes. This paper suggests the questions to be asked and reports to what extent the more popular FFT programs meet the criterion inherent in the questions asked.

\section{METHOD}

We reviewed commercially available programs or very popular programs and three commercially available hardware Fourier analyzers. These programs and hardware are all readily available.

\section{Procedure}

The sources of the data were threefold: (1) the actual running of the FFT programs and hardware analyzers, (2) a review of the literature, and (3) personal communication with other FFT users. The review of the literature was limited to sources readily available to psycholgists (i.e., the IEEE proceedings, the Science Citation Index, and BYTE magazine). We did not review mathematical or engineering journals (except IEEE) or computer science publications.

\section{RESULTS}

Tables $1 \mathrm{a}$ and $1 \mathrm{~b}$ contain general information about the various computer program packages and hardware reviewed. Table $2 \mathrm{a}$ and $2 \mathrm{~b}$ list detailed information on each product listed in Tables $1 \mathrm{a}$ and $1 \mathrm{~b}$. If one of the columns was not applicable or the information was not available for a particular product, the element is listed N/A.

Column headings in Table 1 are self-explanatory; however, the headings in Table 2 require some explana- tion. In the section titled "Inputs," "number of channels" indicates how many channels or variables can be analyzed simultaneously. This is important if a user needs to compare two or more time series over the same time period. This would be the case if cross-power, phase angle, or coherence were required. The maximum number of points that a program can analyze and the sampling rate are critical if analyses are to be performed on-line in a real-time environment. In the section titled "Processes," "epoch summing" refers to the products capability for averaging over multiple epochs. This is a critical feature if the time-series durations to be analyzed last for only a few cycles of the slowest waveform. In the column labeled "Others," we have listed some but not all of the various optional analyses available to the user of the specified package.

\section{DISCUSSION}

Several points should be considered before selecting an FFT program for any particular application. If your time-series data have been collected without the aid of a computer and are not in machine-readable form, then any of the software packages listed in Table 1a can be used if they will give the proper outputs. If you need to have the data analyzed immediately after the events occur or soon thereafter, you will need to use the LSP from Digital Equipment Corporation, the subroutines from ILS, or a hardware FFT product. In some cases, additional software must be written to supplement these subroutines.

An important detail of many FFT programs is that they either require or recommend that the number of data points in the time series be an even power of 2 . This condition becomes particularly acute when sampling physiological signals for analog-to-digital (A/D) conversion. Many timers or clocks are set to run in hundredths or thousandths of $1 \mathrm{sec}$ but not $1 / 256$ or 1,024 fractions of $1 \mathrm{sec}$. The LSP and Spect programs require data points in powers of 2 , and SAS recommends the same (SAS Institute, Inc., 1979). This fact should be taken into account when purchasing the clock for one's A/D converter.

Three solutions exist for fast-turnaround FFT problems. One alternative is to purchase one of the hardware 
Table 1

\begin{tabular}{|c|c|c|c|c|c|c|c|c|}
\hline Product & $\begin{array}{l}\text { Vendor and } \\
\text { Address }\end{array}$ & $\begin{array}{l}\text { Transport- } \\
\text { ability }\end{array}$ & Maintenance & $\begin{array}{c}\text { Docu- } \\
\text { mentation }\end{array}$ & $\begin{array}{l}\text { Ease } \\
\text { of Use }\end{array}$ & Cost & Memory & Applications \\
\hline \multicolumn{9}{|c|}{ (a) Fast Fourier Transform Computer Program Packages } \\
\hline SAS & $\begin{array}{l}\text { SAS Institute, Inc. } \\
\text { P.O. Box } 8000 \\
\text { Cary, NC } 27511 \\
(919) 467-8000\end{array}$ & $\begin{array}{l}\text { IBM 360/370, } \\
\text { Amdahl, Itel, } \\
\text { CDC Omega, } \\
\text { Magnuson, Ryad }\end{array}$ & By subscription & $\begin{array}{l}\text { Very complete } \\
\text { users' guide }\end{array}$ & $E$ & $\begin{array}{l}\$ 1,000 \\
\text { per year }\end{array}$ & $120 \mathrm{~KB}$ & $\begin{array}{l}\text { Flexible, no model } \\
\text { building }\end{array}$ \\
\hline BMDP & $\begin{array}{l}\text { BMDP Statistical } \\
\text { Software } \\
\text { P.O. Box 24A26 } \\
\text { Los Angeles, } \\
\text { CA 90024 } \\
\text { (213)825-5940 }\end{array}$ & $\begin{array}{l}\text { Nearly any } \\
\text { computer } \\
\text { with a FOR- } \\
\text { TRAN com- } \\
\text { piler }\end{array}$ & By subscription & $\begin{array}{l}\text { Very complete } \\
\text { users' manual }\end{array}$ & $\mathrm{M}$ & $\begin{array}{l}\$ 750 \\
\text { per year }\end{array}$ & $120 \mathrm{~KB}$ & Very flexible \\
\hline SPSS & $\begin{array}{l}\text { SPSS, Inc. } \\
\text { Suite } 3300 \\
444 \text { North } \\
\text { Michigan Ave. } \\
\text { Chicago, IL } 60611 \\
\text { (312)329-2400 }\end{array}$ & $\begin{array}{l}\text { IBM 360/370, } \\
\text { CDC 6000, } \\
\text { Cyber, Univac } \\
\text { 1100, Xerox, } \\
\text { Harris, DEC } \\
10 / 20 \& \\
\text { VAX, Honey- } \\
\text { well, Prime }\end{array}$ & By subscription & $\begin{array}{l}\text { Excellent } \\
\text { users' guide }\end{array}$ & $\mathrm{E}$ & $\begin{array}{l}\$ 1250 \\
\text { per year }\end{array}$ & $220 \mathrm{~KB}$ & $\begin{array}{l}\text { Limited, allows } \\
\text { modeling and fore- } \\
\text { casting }\end{array}$ \\
\hline LSP & $\begin{array}{l}\text { Digital Equipment } \\
\text { Corporation Tech- } \\
\text { nical Documenta- } \\
\text { tion Center, 1050 } \\
\text { E. Remington } \\
\text { Schaumburg, } \\
\text { IL 60195 } \\
(312) 640-5612\end{array}$ & DEC PDP-11 & $\begin{array}{l}\text { Optional soft- } \\
\text { ware support }\end{array}$ & $\begin{array}{l}\text { Very complete } \\
\text { programmer's } \\
\text { reference } \\
\text { manual }\end{array}$ & E & $\$ 350$ & $11 \mathrm{~KB}$ & $\begin{array}{l}\text { Limited, can be used } \\
\text { on-line, FORTRAN } \\
\text { callable }\end{array}$ \\
\hline Spect & $\begin{array}{l}\text { V.A. Benignus } \\
\text { MD 58, Environ- } \\
\text { mental Protection } \\
\text { Agency Research } \\
\text { Triangle, } \\
\text { NC } 27711\end{array}$ & $\begin{array}{l}\text { Nearly any } \\
\text { computer } \\
\text { with a FOR- } \\
\text { TRAN com- } \\
\text { piler }\end{array}$ & None & $\begin{array}{l}\text { None other } \\
\text { than by } \\
\text { example }\end{array}$ & D & $\begin{array}{l}\text { Cost of } \\
\text { media }\end{array}$ & $120 \mathrm{~KB}$ & $\begin{array}{l}\text { Flexible, no model } \\
\text { building }\end{array}$ \\
\hline ILS & $\begin{array}{l}\text { Signal Technology } \\
\text { 5951 Encina Rd. } \\
\text { Goleta, CA } 93117 \\
(800) 235-5787\end{array}$ & $\begin{array}{l}\text { Nearly any } \\
\text { computer } \\
\text { with a FOR- } \\
\text { TRAN com- } \\
\text { piler }\end{array}$ & $\begin{array}{l}\text { 1st year free, } \\
\text { thereafter by } \\
\text { subscription }\end{array}$ & $\begin{array}{l}\text { Complete } \\
\text { users' manual } \\
\& \text { training } \\
\text { manual }\end{array}$ & $\mathbf{E}$ & $\begin{array}{l}\$ 7,800- \\
\$ 20,000\end{array}$ & N/A & $\begin{array}{l}\text { Very flexible, FOR- } \\
\text { TRAN callable on- } \\
\text { line }\end{array}$ \\
\hline \multicolumn{9}{|c|}{ (b) Special FFT Computer Hardware } \\
\hline $\begin{array}{l}\text { Intel } \\
80 / 30\end{array}$ & $\begin{array}{l}\text { Intel Corporation } \\
3065 \text { Bowers Ave. } \\
\text { Santa Clara, } \\
\text { CA 95051 } \\
(408) 987-8080\end{array}$ & & $\begin{array}{l}\text { Return to } \\
\text { factory }\end{array}$ & $\begin{array}{l}\text { Incomplete } \\
\text { users' manual }\end{array}$ & $\mathrm{E}$ & N/A & & N/A \\
\hline $\begin{array}{l}\text { Nicolet } \\
440,445 \\
600\end{array}$ & $\begin{array}{l}\text { Nicolet Scientific } \\
\text { Corporation } \\
\text { P.O. Box } 159 \\
245 \text { Livingston St. } \\
\text { Northvale, } \\
\text { NJ 07647 } \\
(201) 767-7100\end{array}$ & & $\begin{array}{l}\text { Return to } \\
\text { factory }\end{array}$ & $\begin{array}{l}\text { Complete } \\
\text { users'manual }\end{array}$ & $\mathrm{E}$ & $\$ 10,000$ & & Flexible \\
\hline $\begin{array}{l}\text { Mars-232 } \\
\text { Array } \\
\text { Processor }\end{array}$ & $\begin{array}{l}\text { Numerix } \\
\text { Corporation } \\
\text { 320 Neddham St. } \\
\text { Newton, } \\
\text { MA 02161 } \\
\text { (617)964-2500 }\end{array}$ & & N/A & N/A & $\mathrm{E}$ & N/A & & Flexible \\
\hline
\end{tabular}

Note $-E=$ easy, $M=$ moderate,$D=$ difficult $; / A=$ not applicable.

products listed in Table $1 \mathrm{~b}$; another is to buy an FFT program for your laboratory computer similar to LSP or ILS. The last alternative is to write your own FFT. Each of these will be considered in turn, indicating what some example systems have and what to watch out for.

The reduced cost of microelectronic components has made special-purpose stand-alone Fourier analyzers 
Table 2

\begin{tabular}{|c|c|c|c|c|c|c|c|c|c|c|c|}
\hline \multirow[b]{2}{*}{ Product } & \multicolumn{3}{|c|}{ Inputs } & \multicolumn{5}{|c|}{ Outputs } & \multicolumn{3}{|c|}{ Processes } \\
\hline & 1 & 2 & 3 & 1 & 2 & 3 & 4 & 5 & 1 & 2 & Other \\
\hline \multicolumn{12}{|c|}{ (a) Fast Fourier Transform Computer Program Capabilities } \\
\hline SAS & 99 & N/A & User specified & Y & $\mathrm{Y}$ & $\mathrm{Y}$ & $\mathrm{Y}$ & Y & $\begin{array}{l}\text { User specified } \\
\text { weights }\end{array}$ & ND & White-noise test \\
\hline BMDP & 2 & $\mathrm{~N} / \mathrm{A}$ & User specified & $\mathrm{Y}$ & $\mathrm{Y}$ & $\mathrm{Y}$ & $\mathrm{Y}$ & $\mathrm{Y}$ & $\begin{array}{l}\text { Default or } \\
\text { user specified }\end{array}$ & $\mathrm{Y}$ & $\begin{array}{l}\text { Inverse, confidence } \\
\text { bands, prefiltering, Box- } \\
\text { Jenkins, modeling }\end{array}$ \\
\hline SPSS & 1 & N/A & User specified & $\mathrm{N}$ & $\mathrm{N}$ & $\mathbf{N}$ & $\mathrm{N}$ & $\mathbf{N}$ & Y & $\mathrm{N}$ & $\begin{array}{l}\text { Model fitting and fore- } \\
\text { casting with Box-Jenkins }\end{array}$ \\
\hline LSP & $1^{*}$ & 8192 & User specified & $\mathbf{Y}$ & Y & $\mathbf{Y}$ & $\mathrm{N}$ & ND & $\mathrm{N}$ & ND & Autocorrelation \\
\hline Spect & 2 & $512 \dagger$ & User specified & $\mathrm{Y}$ & $\mathrm{Y}$ & $\mathrm{Y}$ & $\mathrm{Y}$ & $\mathrm{Y}$ & $\mathrm{Y}$ & $\mathrm{Y}$ & $\begin{array}{l}\text { Probability density, } \\
\text { many transformations, } \\
\text { proportional power, } \\
\text { regression }\end{array}$ \\
\hline ILS & $1^{*}$ & $\mathrm{~N} / \mathrm{A}$ & User specified & $\mathrm{Y}$ & Y & $\mathrm{Y}$ & $\mathrm{Y}$ & $\mathrm{Y}$ & $\mathrm{Y}$ & $\mathrm{Y}$ & $\begin{array}{l}\text { Filtering, modeling, } \\
\text { convolution, 3-D displays, } \\
\text { pattern recognition }\end{array}$ \\
\hline \multicolumn{12}{|c|}{ (b) Fast Fourier Transform Hardware Capabilities } \\
\hline Intel $80 / 30$ & 2 & 7000 & $500 \mathrm{~Hz}$ & $\mathrm{Y}$ & $\mathrm{N}$ & $\mathrm{N}$ & $\mathrm{N}$ & $\mathrm{N}$ & $\mathrm{Y}$ & $\mathrm{Y}$ & \\
\hline $\begin{array}{l}\text { Nicolet } 440 \\
445,600\end{array}$ & $\begin{array}{l}1 \\
2\end{array}$ & $\mathrm{~N} / \mathrm{A}$ & N/A & $\mathrm{Y}$ & N/A & $\mathrm{Y}$ & $\mathrm{Y}$ & $\mathrm{Y}$ & N/A & $\mathrm{Y}$ & N/A \\
\hline $\begin{array}{l}\text { Mars-232 Array } \\
\text { Processor }\end{array}$ & $\mathrm{N} / \mathrm{A}$ & $\mathrm{N} / \mathrm{A}$ & Up to $5 \mathrm{MHz}$ & $\mathrm{Y}$ & $\mathrm{N} / \mathrm{A}$ & N/A & $\mathrm{N} / \mathrm{A}$ & N/A & N/A & $\mathrm{N} / \mathrm{A}$ & Image analysis, filtering \\
\hline
\end{tabular}

Note $-Y=y e s, N=$ no, $N D=$ not directly, $N / A=$ not applicable. Inputs: $1=$ number of channels, $2=$ maximum points, $3=$ sampling rate. Outputs: 1 = power spectra, 2 = amplitude spectra, $3=$ cross-power, $4=$ coherence, $5=$ phase spectra. Processes: $1=$ smoothing functions, 2 = epoch summing. $\quad *$ Per call. $\quad$ fPer epoch.

financially feasible. As an example, the Intel 80/30 spectral analysis system provides for on-line spectral analysis of low-frequency signals. Fifty-eight data bursts or epochs of $128 \mathrm{msec}$ duration can be resolved from 0 - to $500-\mathrm{Hz}$ frequency bands with a resolution of $8 \mathrm{~Hz}$. Frequency centroids that divide the specturm into low- and high-energy bands are calculated for each data burst. From one to eight data bursts per second may be collected for analysis. The system provides three output forms: CRT time history plots of the frequency spectra using an orthogonal projection technique, a CRT plot of the change in centroid frequency over the 58 epochs, and ASCII character codes over an RS-232 line with a 9,600 maximum baud rate. The microcomputer-based Intel system reported here has been used primarily for real-time analysis of electromyographic signals monitored by attaching small electrodes to the surface of the skin in the area of muscle under study. The system requires incoming bioelectric analog signals between $+1.25 \mathrm{~V}$ and $-1.25 \mathrm{~V}$. It contains its own $\mathrm{A} / \mathrm{D}$ converter and uses an FFT algorithm for the analysis. Two channels of 0 to 250 passband-filtered data are sampled at $500 \mathrm{~Hz}$ for the analyses. The samples in each epoch can be weighted with a Blackman Window. Data amplitudes are digitized into 12 bits. Simple one-letter commands from a keyboard are used to set the system for data acquisition and analysis. Data acquisition is initiated only when an external trigger is activated. Unfortunately, the system available to us had a fixed $8 \cdot \mathrm{Hz}$ window that made the system unusable for most EEG, $\mathrm{EP}, \mathrm{EKG}$, and other physiological work requiring greater resolution. The Nicolet 660 is much more flexible in this regard, but at a higher price.

The LSP is a good example of a set of laboratory computer subroutine programs that can be called from FORTRAN in an on-line environment. Although these subroutines are self-contained, they do require some software development to integrate them with the values coming from an A/D converter. The expenses for programming are over and above the cost of the FFT package unless the researcher or the students of the researcher can create the necessary programs. The limitations in the LSP package indicated in Table $2 \mathrm{a}$ can be remedied with extra programming as well.

With regard to the last alternative, writing your own FFT program, a few sources can be recommended for computers with a FORTRAN compiler. Brigham (1974) has an excellent book on the Fourier transform and lists the FFT in the appendix. Versions of the FFT written in BASIC can be found in Ruckdeschel (1979) and Stanley and Peterson (1978). If you have a low budget, a microcomputer, a small amount of data, and lots of time to wait, these routines will satisfy your requirements. To make your microcomputer faster, you need to program the FFT in assembly language. Lord (1979) has a program for any computer with a 6800 Motorola CPU, and Zimmerman (1981) has an assembly language FFT for the $6502 \mathrm{CPU}$ in a PET microcom- 
puter. These programs are more tutorial than production oriented, but anyone who can make them run can modify them as needed. ${ }^{1}$

One last point to consider before buying an FFT program for time-series analysis is that there are many imitators on the market. The SPSS system of timeseries analysis not only has many limitations for electrophysiological data analysis but does not use the FFT algorithm (Nie, Hull, Jenkins, Steinbrenner, \& Bent, 1975). It does, however, contain many features that social scientists find useful. The program is easy to use because it conforms to standard SPSS command format, allowing data transforms, standard data formatting, and integration with other statistical programs. The SPSS program uses the Box-Jenkins algorithm to fit and forecast time-series data. The SPSS, Version 9, routine can analyze a univariate time series only with observations that are equally time spaced and have no missing values. The program allows forecasting of data based on a model built from the data's past values. Both seasonal and nonseasonal lags can be incorporated into the predictive model.

The forecasting of times-series data is usually performed in three steps: (1) A tentative model is identified, (2) parameter estimates are tried in order to generate statistics and plots for examination, and (3) a set of forecasts are printed. Model building that culminates in an adequate forecast typically entails several computer runs. No power spectral plots or amplitude plots are available from this package, although autocorrelograms and partial autocorrelation functions are readily available. Do not let your friendly academic computing center consultant try to tell you that you can analyze A/D converted electrophysiological data with SPSS. It will not give you what you need. Either BMDP
(Dixon, 1981) or SAS should be considered for this purpose.

In summary, there is a wide choice of FFT programs and FFT analyzers available. However, psychologists are by and large consumers of data analysis techniques; that is, psychologists are consumers of statistics rather than originators of statistical equations. Similarly, psychologists are consumers of the FFT programs. They want to "run" programs not write them. There are certain questions a wise consumer needs to ask. The more important of these questions are discussed in this paper.

\section{REFERENCES}

Benignus, V., \& Muller, K. E. Information flow in the brain: Computer requirements (A tutorial). Behavior Research Methods \& Instrumentation, 1982, 14, 294-299.

Brigham, E. O. The fast Fourier transform. Englewood Cliffs, N.J: Prentice-Hall, 1974.

Dixon, W. J. (Ed.). BMDP statistical software (1981 ed.). Berkeley: University of California Press, 1981.

Lond, R. H. Fast Fourier for 6800. Byte, 1979, 4, 108-119. Nie, N. H., Hull, C. H., Jenkins, J. G., Steinbrenner, K., \& Bent, D. H. Statistical package for the social sciences (2nd ed.). New York: McGraw-Hill, 1975.

RuCKDESCHet, F. R. Frequency analysis of data using a microcomputer. Byte, 1979, 4, 10-34.

SAS INBTItUTE, Inc. SAS user's guide. Raleigh, N.C: Author, 1979.

Stanley, W. E., \& Peterson, S. J. Fast Fourier transforms on your home computer. Byte, 1978, 3, 14-25.

Zimmerman, M. A beginner's guide to spectral analysis. Byte, $1981,6,68-78$.

\section{NOTE}

1. Benignus and Muller (1982) present a tutorial approach covering mathematical, statistical, and experimental design considerations needed to design a computer system for EEG data acquisition, spectrum and cross-spectrum analyses. 